\title{
IAMJ
}

INTERNATIONAL

AYURVEDIC

MEDICAL JOURNAL

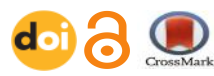

\section{PATHYAPATHYA IN PRAMEHA}

\section{Ripsa Raj K. P1 , P Sudhakar Reddy ${ }^{2}$}

${ }^{1}$ Final year P.G Scholar, Department of P G Studies in Swasthavritta, JSS Ayurveda College, Mysuru, Karnataka, India.

${ }^{2}$ Professor \& Head, Department of P G Studies in Swasthavritta, JSS Ayurveda Medical College, Lalithadripura Road, Mysuru -570028 Karnataka, India.

\section{Corresponding Author: ripsthedoctor@gmail.com}

https://doi.org/10.46607/iamj3309082021

(Published Online: August 2021)

Open Access

(C) International Ayurvedic Medical Journal, India 2021

Article Received: 21/07//2021 - Peer Reviewed: 02/08/2021 - Accepted for Publication: 03/08/2021

\section{Check for updates}

\begin{abstract}
Diabetes mellitus is becoming the fastest considerable disease in the world. India has been estimated with the fastest-growing population of Diabetics. According to International Diabetic Federation (IDF), the total number of Diabetic subjects will be around 151 million in India by 2045. The clinical entity of Prameha can be correlated with Diabetes Mellitus. It is considered a Lifestyle disorder, the food, drinks and sedentary habits are having a great influence on this disorder. In Ayurveda classics elaborately mentioned the Nidana (causative factors) and Pathya ahara (wholesome food \& drinks) and Apathya ahara (unwholesome food \& drinks), Pathya Vihara (Conducive lifestyle) and Apathya Vihara (Non-Conducive lifestyle) of Prameha. The classification of Prameha as per Susruta Samhita as Apathya nimittaja Prameha and Beeja doshaja Prameha indicates the importance of Ahara and Vihara in prevention as well as management of this disease. In this article, a sincere attempt has been made to incorporate the principles of Ayurveda and Modern medical science with a scientific explanation regarding Pathya (Diet) and Vihara (lifestyle) in Prameha (Diabetes Mellitus).
\end{abstract}

Keywords: Pathya, Apathya, Prameha, Ahara, Vihara. 


\section{INTRODUCTION}

According to Ayurveda in every food, some factors are developing the mental faculties and certain other factors developing the physical built of the body ${ }^{3}$. Acharya Charka, Sushruta and Vagbhata also mentioned development, perspicuity of Indriyas, happiness clarity of voice, lustre, pleasure, increase of Dhatus, intellect, health etc. Kasyapa explained that food is said to be the cause of stability for all living beings. There is nothing else except diet for sustaining the life of a living being. Any other medicament just like diet is not available; one is capable to make man disease free only with cereals (congenital diet). One is not able to sustain life without diet even if endowed with medicine that is why the diet is said to be the great medicament by a physician. Charaka explained that people who use Hitaahara (suitable foods) only in the disease caused by food do not develop. The unsuitable food, i.e., Ahitahara leads to disease. In Shabdakalpadruma, it is explained that Pathya as Hitakara to Rogi (diseased person) and Apathya leads to death. Chakrapani explains that comforting the mind and not creating disease in it to be considered as Pathya (beneficial), whereas that which is uncomfortable to mind and causing disease is called Apathya(unbeneficial). Charaka again explains that Pathya is that which is the right path, which does not create any trouble, and which is pleasant $\backslash$ agreeable to the mind, that which is unpleasant to mind is Apathya. He explains that Pathya is of a different kind, proper Matra (quantity) of Ahara leads to Pathya and improper Matra leads to Apathya. Diabetes is increasing over the globe at an alarming rate. It is a chronic disease that occurs either when the pancreas does not produce enough insulin or when the body cannot effectively use the insulin it produces. India has an estimated 77 million people with Diabetes, which makes it the second most affected in the world. Type 1 Diabetes is rarer than in western countries. Only about 0ne-third of type 2 Diabetics in India are overweight or obese ${ }^{1}$. The studies show that environmental and lifestyle changes, industrialization, genetic factors etc. lead to this. In Ayurveda, Diabetes Mellitus is considered under the broad clinical entity Prameha. The person indulging in Atiahara (excess intake of food), Atidrava Annapana (liquid food and drinks) and Vihara like Avyayama (without exercise), Divaswapna (day sleep), Atinidra (excess sleep) etc. are prone to Prameha ${ }^{2}$. Ayurveda classics mentioned that Apathya Ahara Vihara leads to Prameha, they are vastly explained about the Pathya and Apathya in Prameha.

\section{PATHYAHARA IN PRAMEHA}

Prameha is one of the Ashtamahagada, so it is Kruchrasadhya and mostly Asadhya (incurable) Vyadhi $^{2}$. In this type of Vyadies, Chikitsa is very difficult, so Ayurveda classics mentioned Pathya- apathya to establish the treatment procedures by the maintenance of Ahara and Vihara.

TABLE 1: Pathyahara

\begin{tabular}{|l|l|l|l|l|l|l|l|}
\hline NO & PATHYAHARA & CH. S & A.H & SU.S & B. P & B. R & Y. R \\
\hline 1 & Mantha & + & - & - & - & + & - \\
\hline 2 & Masoora & - & - & - & - & + & - \\
\hline 3 & Mudga & + & - & + & + & + & + \\
\hline 4 & Syamaka & - & - & - & + & + & + \\
\hline 5 & Kodrava & - & - & - & + & + & + \\
\hline 6 & Uddalaka & - & - & + & + & + & + \\
\hline 7 & Canaka & - & - & + & + & + & + \\
\hline 8 & Aadaki & - & - & + & + & + & + \\
\hline 9 & Kulatha & - & - & + & + & + & + \\
\hline 10 & Puranasali & + & - & - & + & + & + \\
\hline 11 & Tiktasaka & + & + & + & + & + & + \\
\hline 12 & Yava & + & - & + & + & + & + \\
\hline
\end{tabular}




\begin{tabular}{|c|c|c|c|c|c|c|c|}
\hline 13 & Madhu & - & + & - & - & - & - \\
\hline 14 & Laja & - & - & - & - & + & - \\
\hline 15 & Patola & - & - & - & - & + & + \\
\hline 16 & Karavellaka & - & - & - & - & + & - \\
\hline 17 & Karkoataka & - & - & - & - & + & - \\
\hline 18 & Lasuna & - & - & - & - & + & + \\
\hline 19 & Godhuma & + & - & - & + & + & + \\
\hline 20 & Takra & - & - & - & - & + & - \\
\hline 21 & Kharjura & - & - & - & - & + & - \\
\hline 22 & Vyagri & - & - & - & - & + & - \\
\hline 23 & Udumbara & - & - & - & - & + & - \\
\hline 24 & Naveenamoca & - & - & - & - & + & - \\
\hline 25 & Kalindaphala & - & - & - & - & + & - \\
\hline 26 & Vishkiramamsa & + & - & - & + & + & - \\
\hline 27 & Pratuda mamsa & + & - & - & + & + & - \\
\hline 28 & Jangalamamsa & + & + & - & + & + & + \\
\hline 29 & Prasahamamsa & + & - & + & - & - & - \\
\hline 30 & Vareecarmamsa & + & - & - & - & - & - \\
\hline 31 & Saindhava & - & - & - & - & - & + \\
\hline 32 & Mareeca & - & - & - & - & - & + \\
\hline 33 & Sura & - & - & - & - & + & - \\
\hline 34 & Seedhu & + & - & - & - & - & - \\
\hline 35 & Saktu & + & - & - & - & - & - \\
\hline 36 & Guda & + & - & - & - & - & - \\
\hline 37 & Jamboophala & - & - & + & - & - & - \\
\hline 38 & Tintukaphala & - & + & + & - & + & - \\
\hline 39 & Danti taila & + & - & + & - & - & - \\
\hline 40 & In gudee taila & + & - & + & - & - & - \\
\hline 41 & Ataseetaila & + & - & + & - & - & - \\
\hline 42 & Sarshapa taila & + & - & + & - & - & - \\
\hline 43 & Shashtika & + & - & - & - & - & - \\
\hline 44 & Trunadhanya & + & - & - & - & - & - \\
\hline
\end{tabular}

Table 2: Patyavihara

\begin{tabular}{|l|l|l|l|l|l|l|l|}
\hline NO & Pathyavihara & CH. & A.H & SU.S & B. P & B. R & Y. R \\
\hline 1 & Vyayama & + & + & - & - & + & - \\
\hline 2 & PragaDha & + & + & - & - & - & - \\
\hline 3 & Udvartana & + & + & - & - & - & - \\
\hline 4 & Snana & + & - & - & - & - & - \\
\hline 5 & Jalavaseka & + & - & - & - & - & - \\
\hline 6 & Nisijagarana & - & + & + & - & + & - \\
\hline 7 & Parikramana & - & + & + & - & + & - \\
\hline 8 & Hastysvavahana & - & + & + & - & + & - \\
\hline 9 & Yudha & - & - & + & - & - & - \\
\hline 10 & Ravitvit & - & - & - & - & + & - \\
\hline
\end{tabular}


Table 3: Apathyahara

\begin{tabular}{|c|c|c|c|c|c|c|c|}
\hline NO & APATHYAHARA & CH.S & A.H & SU.S & B. $\mathbf{P}$ & B. $\mathbf{R}$ & Y.R \\
\hline 1 & Navadhanya & + & + & - & - & - & - \\
\hline 2 & Atidhanya Sevana & + & - & - & - & - & - \\
\hline 3 & Navasimbhidhanya & + & - & - & - & - & - \\
\hline 4 & Jramyamamsa & + & - & + & - & - & - \\
\hline 5 & Aanoopamamsa & + & - & + & + & + & + \\
\hline 6 & Audakamamsa & + & - & + & - & - & - \\
\hline 7 & Navanna & + & - & - & - & + & + \\
\hline 8 & Saakani & + & - & - & - & - & - \\
\hline 9 & Tila & + & - & - & - & - & - \\
\hline 10 & Pishtanna & + & - & + & + & - & + \\
\hline 11 & Payasa & + & - & - & - & - & - \\
\hline 12 & Krusara & + & - & - & - & - & - \\
\hline 13 & Vilepi & + & - & - & - & - & - \\
\hline 14 & Ekshurasa & + & - & + & + & - & + \\
\hline 15 & Guda & - & + & - & + & - & + \\
\hline 16 & Ksheera & + & - & + & + & - & - \\
\hline 17 & Dadhi & + & - & + & - & + & + \\
\hline 18 & Sura & - & + & + & + & - & + \\
\hline 19 & Toya, Dustajala & - & - & + & - & + & - \\
\hline 20 & Taila & - & - & + & + & - & + \\
\hline 21 & Grita & + & - & + & + & - & + \\
\hline 22 & Panaka & - & - & + & - & - & - \\
\hline 23 & Amlarasa & + & - & + & + & + & + \\
\hline 24 & Lavanarasa & - & - & - & - & + & - \\
\hline 25 & Sowveeraka & - & - & + & + & - & + \\
\hline 26 & Virudhanna & - & - & - & - & + & - \\
\hline 27 & Medhyannapana & - & + & + & - & + & - \\
\hline 28 & Dravannapana & - & - & + & - & - & - \\
\hline 29 & Takra & - & - & - & + & - & - \\
\hline
\end{tabular}

Table 4: Apathyavihara

\begin{tabular}{|l|l|l|l|l|l|l|l|}
\hline NO & Apathyavihara & CH.S & A.H & SU.S & B. P & B. R & Y. R \\
\hline 1 & Aasyasukha & + & + & - & + & + & + \\
\hline 2 & Swapnasukha & + & - & - & + & - & - \\
\hline 3 & Divaswapna & + & - & + & - & + & + \\
\hline 4 & Srama & + & - & - & - & - & - \\
\hline 5 & Krodha & + & - & - & - & - & - \\
\hline 6 & Soka & + & - & - & - & - & - \\
\hline 7 & Ativyavaya & + & - & - & - & + & - \\
\hline 8 & Vidhivarjitasayana & + & + & - & - & + & - \\
\hline 9 & Vegasamdharana & + & - & - & - & + & + \\
\hline 10 & Anasana & + & - & - & - & - & - \\
\hline 11 & Abhighata & + & - & - & - & - & - \\
\hline 12 & Sonitamoksha & + & - & - & - & + & + \\
\hline 13 & Udvega & + & - & - & - & - & - \\
\hline 14 & Jagarana & + & - & - & - & - & - \\
\hline
\end{tabular}




\section{DISCUSSION}

Pathya- Ahara (Wholesome Diet)

a. Sukadhanya Varga (Cereals): -

i. Sali (Rice), in this Purana Sali (Old rice) is Pathya and Navanna is Apathya. Purana Sali is the rice that harvests and is used after one year or more, it is Laghu (light) in the property. Madhura Rasa (sweet taste) and Singdha guna (unctuous). It is Mootrala (increase the quantity of urine), and Vrushya (aphrodisiac). It is easily digestible, Kashayanurasa (astringent after taste). Navanna (freshly harvested rice) is Guru (heavy) and increase the Kapha Dosha. Glycemic index of rice is 73, and it is very high. Shashtika is a Vrihi Dhanya. It is Snigdha, Grahi (constipate), Madhurarasa, Sita (cool), pacifies Tridoshas and provides stability ${ }^{7}$. Grahi is the property that which prevents the loss of water from the body, Prameha patient suffering from excessive loss of water from the body it can prevent by use of this ${ }^{15}$. ii. Godhuma (wheat) is Vrusya, Sita, Guru, Snigdha, Jivana (enlivening), pacifies Vata and Pitta, increase body strength and laxative ${ }^{8}$. Chakrapani explains that fresh Godhuma causes an increase of Kapha whereas Purana Godhuma (old one) does not increase Kapha. Wheat is a good source of protein, carbohydrates, rich in fibre both soluble and insoluble, vitamin B, minerals including iron, magnesium. Glycemic index is $54^{16}$.

iii. Yava (barley- hordeum vulgare) is Ruksha (dry), Sita, Guru, and Madhurarasa. It is laxative, generates faeces and Vata in intestines is Vrusya and increases stability $^{8}$. It controls diseases of the urinary tract, corrects disorders of fat metabolism. It is rich in dietary fibre $17 \mathrm{~g}$, iron, vitamin B-6, and magnesium, low in glycemic index 26 to 30

b. Truna Dhanya (millets) like Syamaka (little millet), Kodrava (kodo millet), they are sweet, Sita (cool) Laghu, increase Vata, are Lekhanna (abrasive) and pacify Kapha and Pitta ${ }^{8}$. It contains high fibre and a low glycemic index. The Glycemic index is between 54 to 68 . They are rich in calcium, dietary fibre, polyphenols, and protein. The fibre content is 19.1 to 30.8 per cent. c. Samidhanyavarga (pulses): - Acharyas explained that excess use of Dhanya and Navasimbidhanya are Apathya for Prameha. Mudga (green gram) Masura (lentil), Canaka (chickpea), Adhaki (tur dhal), Tila (sesame) are Laghu, mitigate Kapha and Vata and pungent after digestion, Kulatta is hot in potency, these properties will help to reduce Kapha and maintained the blood sugar level ${ }^{7}$. The preparations made by these like Yoosha, etc. are good for Diabetes. They contain dietary fibre, vit$\operatorname{amin}$ A, Vitamin C, iron, vitamin B -6, and Magnesium, zinc, and folate. Phytochemicals, saponins and tannins found in pulses possess antioxidant effects. They are high in fibre and have a low glycemic index ${ }^{24}$.

d. Mamsa Varga: - Flesh of animals and birds which are used for meat are coming under this classification. Acharya Charaka mentioned that Viskira Mamsa (gallinaceous birds), Prasaha Mamsa (animals and birds who eat by snatching), Jangala Mamsa (animals of the desert-like regions), Varicarina (birds which swim in water), Pratuda Paksi (pecking birds), these are Pathya for Diabetic patients and Gramya Mamsa (domestic animals), Anupamrga Mamsa (animals inhabiting marshy land), Audhaka Mamsas (animals living in water) are Apathya.

Viskira, Pratuda, and Jangala Mamsa are easy to digest, Seeta Virya, sweet and slightly astringent in taste and beneficial to persons who have a great increase of Pitta, a moderate increase of Vata and mild increase of Kapha. Prameha is a state of Kapha that increases the body and leads to metabolic disorders so the Mamsa of this group will help to maintain the Tridoshas ${ }^{9}$.

The meat of Prasaha, Varicara groups is hard to digest, Ushnavirya, unctuous, sweet, increase strength and body growth, are aphrodisiac, mitigate Vata, greatly aggravates Kapha and Pitta, suitable to a person who do physical exercises daily and who have strong digestive power; Prameha Rogi also suffering from Atyagni for this condition to maintain the Agni Bala without causing defects in body Guru and Ushnavirya property of the Mamsa will help. 
According to Acharya susruta, Gramya, Anupamamsa are Madhura in Rasa and Vipaka, pacify Vata, increase Kapha and Pitta, promote Dhatus, strength and digestive power; Anupamamsas are especially diuretic, so these are Apathya because Madhura rasa and diuretics are contraindicated for Prameha Rogi.

e. SAKA VARGAS (group of vegetables): Acharya Charaka explains that all Saka Vargas expect Tiktasakas are Apathya. Whereas Baishajya Ratnavali mentioned that Patola (pointed gourd), karavella (Bitter gourd), Karkotaka, Lasuna, Udumbara, are Pathyaaharas.In this Patola is bitter, pungent in Vipaka, pacifies Kapha Pitta, slightly increases Vata, it is digestive, good for heart, aphrodisiac, increase digestive fire, Laghu, unctuousness, hot in potency. It is a good source of vitamins and minerals. It is low in glycemic index and rich in fibre and high in nitrates and it is good for Diabetes mellitus and Blood pressure. Karavella is cold in potency, Laghu, bitter in taste, but does not increase Vata, and kindles digestive fire $^{25}$. A compound called charantin in bitter gourd keeps the sugar levels low and bitter gourd has great benefits of controlling blood sugar. Karkotaka (small bitter ground) it is Tikta Katu Rasa, Seeta virya, Vipaka katu, Deepana, Arucinasana, Kapha Vatahara. Susruta considered it is same as Karavella. The Glycemic index of Bitter gourd is 117. Bitter gourd contains an insulin-like compound called Polypeptide-p or p-insulin which has been shown to control diabetes naturally. Lasuna (Garlic) is coming under Haritakyadi Varga, it has five tastes and is devoid of the sour taste, its seeds are sweet. It is nursing, aphrodisiac, unctuous, hot in potency, digestive, laxative, pungent both taste and after digestion, penetrating, causes the aggravation of Pitta and Rakta (blood), rejuvenator, it cures lots of diseases disease of Vata origin and Kapha origin ${ }^{23}$. Garlic not rich in carbohydrates can influence the blood sugar level and the low Glycemic index - 30, it is also a good source of Vitamins B-6 and Vitamin B-6 involve carbohydrate metabolism. Vitamin $\mathrm{C}$ also play a role in maintaining blood sugar levels, the normal metabolism of carbohydrate is restored after the administration of vitamin $\mathrm{C}$, so the action of vitamin $\mathrm{C}$ is similar to insulin ${ }^{17}$. Vyaghri Phala (prickly brinjal) it is coming under Guducyadi Varga, its fruit is pungent in taste and also after digestion, hot in potency, cause more elimination of semen is purgative, bitter in taste, increase Pitta and digestive fire, easily digestible, mitigates Kapha, Vata, worms, and disorders of fat, eliminates. The glycemic index is 10 which fall under the low GI category. It is low in carbohydrates and rich in fibre so it plays a major role in regulating blood glucose. Fibre is also known to improve lipid abnormalities. Udumbara (cluster fig) is cold yes, potency, Rooksha, Guru, sweet and astringent in taste, promotes complexion diminish the Pitta, Kapha and Rakta ${ }^{18}$. The glycemic index of fig is 51 which fall under the low GI category. These are tremendously high on fibre; it takes the longest to digest so it does not metabolize quickly.

f. Phala Varga (fruits): Naveena mocaphala (plantain), is sweet, cold in potency, sweet after digestion, heavy, is aphrodisiac, stoutening, cures excess hunger, thirst, diseases of eyes, diabetes, increases taste and Mamsa(muscle $)^{11}$. It is the source of vitamin B6, fibre, potassium, magnesium, vitamin $\mathrm{C}$, it has a glycemic index of 40 . Which means they will have a slow but sustained impact on blood sugar. It is protein-rich and fibre-rich which prevent an overall glycemic load of the meal and limit any increase in blood sugar levels. Jambuphala (java plum) is Kashaya Madhurarasa, katu Vipaka, it increases Vata and pacifies Kapha and Pitta $^{14}$. It contains dietary fibre $0.6 \mathrm{~g}$, carbohydrates $14 \mathrm{gm}$, energy $60 \mathrm{KCL}$, fat 0.23 . In folklore practice, it is used wildly as an antidiabetic drug. Tintidikaphala (sumac) when unripe, pacifies Vata and increases Pitta and Kapha while the ripe fruit is hot, appetizer, relishing and pacifies Kapha and Vata. It is Amla (sour), Laghu (light for digestion) Ruksha (dry), Vipaka (after digestion) also $A m l a^{19}$. The studies show that the Sumac power had shown good results in reducing the blood glucose level. Further studies are on the track. 
Kalindaphala (watermelon) ripen fruit is hot in potency, slightly alkaline, aggravates Pitta and mitigates Kapha and Vata ${ }^{19}$. The Glycemic index of watermelon is 72 , but a GI of $2 \operatorname{lgm}$. It contains $91 \%$ of water, low in protein, carbohydrate, fat, and fibre. It is a good source of vitamin C, it provides $23.2 \mathrm{mg}$ of the vitamin. Kharjura (date palm fruit) are cold in potency, sweet in taste and after digestion, unctuous, good for heart, cures bleeding disease, bestows nourishment, strength and semen, mitigates Vata in the alimentary tract, cures fever, thirst, diseases of Vata Pitta, and other diseases caused by drinking wine ${ }^{19}$. Glycemic index of 46 to 55, it is low in fat and protein but rich in sugar, mainly fructose and glucose, the minerals selenium, copper, potassium, and magnesium. Major vitamin B complex and vitamin $\mathrm{C}$, high in dietary fibre $(8.0 \backslash 100 \mathrm{~g})$, insoluble dietary fibre was the major fraction of dietary fibre in dates.

g. Gorasa Varga (group of milk and its products): Ksheera (milk) and Dhadi (curd) is Apathya but according to Bhyshajyaratnavali, Takra (buttermilk) is Pathya for Prameharogi. It is constipating, astringent sour in taste, sweet after digestion, easily digestible, hot in potency, kindles digestive fire, aphrodisiac, bestows nourishment, mitigates $V a t a$, being astringent, hot potency opening up the pores and creating dryness it mitigates Kapha. He who uses Takra daily does not suffer from the disease, and diseases cured by Takra do not recure, just as Amrita (nectar) if for Gods Takra is for humans. It is rich in source of Potassium, calcium, phosphorus, vitamin B12 \& riboflavin. Glycemic index is very low 15 to 33 , but it is very high on insulin index 90 to $98^{20}$.

h. Sindhava (salt): Lavana is Pathya according to Yogarathnakara, has slight Madhura rasa, is Vrusya (aphrodisiac), Hrudya (stomachic) pacifies Tridoshas. It is Laghu, not much Ushna, desirable for eyes, does not produce Vidhaha (burning sensation) during digestion and is carminative. It is low in the Glycemic index.

i. Mareecha (black paper) is coming under the Hareetakyadivarga, Pungent in taste, penetrating, augments digestive fire, mitigates Kapha, and vata, hot in potency, increase Pitta, causes dryness $^{21}$. It is an important healthy food owing to its antioxidant, antimicrobial potential and gastroprotective modules. It contains mainly potassium, calcium, iron and magnesium.

j. Madya Varga: In the group of fermented beverages, wines etc. among them, Seedhu (preparation from cooked sugarcane juice), Saktu is Pathya. Seedhu is best among the Madyavarga, improves voice, digestive fire, strength and colour, increase Vata and Pitta, cures constipation, obesity, piles, enlargement of abdomen and diseases of Kapha origin. It produces instant Vata, Pitta and Snigdha. It contains mainly fibre and sugar

k. Iksu Varga (group of sugarcane juice and its products): Guda (jaggery) is Pathya according to Acharyacharaka, it increases worms, bone marrow, blood, fat, and muscle tissues. It contains sucrose and fructose, iron, and magnesium, the glycemic index is high 84. Other Acharya's mentioned that Guda is Apathya.

1. Taila Varga (group of oils): Danti Taila (Baliospermummontanum Mull), Ingudeetaila, Atasitaila and Sarshapa Tailas are Pathya for Prameharogi. Acharya Charaka explained that Atasi Taila (linseed oil) is sweet and sour, pungent after digestion, hot in potency, beneficial in aggravation of Vata and aggravates Rakta and Pitta ${ }^{22}$. It is rich in fibre and omega-3 fatty acids, due to their high fibre content, flax seeds are considered a low-glycemic food. Flex seeds contain high amounts of lignan, which act as a powerful antioxidant, which improves insulin sensitivity. Sarsapa Taila (mustard oil) is pungent, hot in potency, aggravates Kapha and is best to cure Vatarakta (gouty arthritis), heart disease etc ${ }^{22}$. It does not damage beta cells of pancreas glands but enhances the activity of beta cells to secrete more insulin to convert glucose into energy. Elaidic acid and vita$\min \mathrm{E}$ are the protective measures for insulin both are rich in mustard oil. Inguditaila (Balanites aegyptiaca), Tikta Rasa, hot in potency, Katurasa after digestion, and it pacifies Kapha\&Vata ${ }^{22}$. 
According to Bhavaprakasa and Yogaratnakara, all Tailas are Apathya for Prameha.

m. Jalavarga (group of waters): Acharya Susrutha mentioned that Dravannapanadi's (liquid food and drinks) are Apathya for Prameha and in Bhyashajya Ratnavali Dustajala. It induces all Doshas, Acharya Bhavamisra mentioned that the person who uses Dushtajala will suffer from, thirst, distention, chronic fevers, indigestion, blocking of channels, itching and lymphadenitis. Water taken in is digested in six hours.

\section{VIHARAS}

\section{Pathyaviharas:}

Vyayama feeling of lightness of body, capacity to do work, mitigation of aggravated Doshas, mainly Sleshmakshya (decrease of Kapha) or Tridoshakshaya (decrease of all the three Doshas) due to increase of digestive power mentioned in Ayurveda. It prevents and minimizes weight gain, reduction in blood pressure, improvement in insulin sensitivity and glucose control and optimization of lipoprotein profile.

Udvartanam (upward massage with powdered drugs) disintegrates Kapha, dissolves away fat, removes heaviness of body and uncomfortable feeling of sweat. It opens up the minute channels and improves blood circulation and lymphatic drainage.

Snana (bath) removes fatigue, eliminates sweat, pacifies blood, stimulate the digestive system, Ojaskara (promotes strength and vitality). According to Yogaratnakara hot water bath destroys the Kapha and Vata.

Nisijagarana (awaking at night) those who suffering from Kapha, fat and poison awaking at night is beneficial. Sleep is induced due to Kapha and Tamas.

Parikramana (walking on foot), Hastiaswavahana (elephant or horse riding), Yudha (wrestling), all are activities that reduce the excess Kaha and fat.

\section{Apathyaviharas}

Asyasukha (sitting a long time) will leads to increase Kapha and accumulate body fat. Decrease the metabolic activity and circulation of blood.

Swapnasukha (long sleep) is also producing excess Kapha and leads to the accumulation of fat in the body tissues, reduce the metabolic rate. Obesity and emaciation are produced by excess and long sleep.

Divaswapna (day sleep) leads to many diseases, obstruction of channels, increase fat accumulation etc.

Srama (excessive physical activities), suppression of urges, not ingesting food, assault, injury, more of emotions, grief, letting of blood in more quantity, keep awake at night, keep the body in irregular (unnatural posters) by these Vata gets aggravated and leads to dryness of body and fatigue. This aggravated Vata accumulates in the body and Ojokshaya will happen.

\section{CONCLUSION}

Ayurveda considered that Prameha is Yapya Roga which is incurable, maintained by Pathyaharaviharas and medicine. Considering the Nidana and Pathayapathya of Prameha, it can be maintained well for improving the quality-of-life Diabetic patient. Modern medicine considered Diabetes is a non-communicable $\&$ lifestyle disorder. A sedentary lifestyle will lead to Diabetes at the earliest. If we consider this Pratyahara and Pathyavihars shows the clear-cut pathway to avoid the disease by maintaining perfect lifestyle. Tridoshas are involved in this and Ojokshya is the main course for the disease pathology. So, the food and drinks which leads to Ojosamrakshana and Balavardhana but never cause an increase of Doshas and Medodhatu is considered as an ideal food for the Prameharogi.

\section{REFERENCES}

1. American Diabetes Association Lifestyle management: Standards of medical care in Diabetes Care. 2018: Pages- 51-54.

2. Dr Ramakaran Sharma and Vaidya Bhagvan Dash, Charaka Samhitha based on Chakrapani dathas Ayurveda Dipika, Chawkhamba Sanskrit Studies Vol. XCIV. 2013, Vol. XCIV.- chapter-6- Prameha. pages298-316

3. Prof. K.R. Srikantha Murthy, Susrutha Samhitha. Vol.I, Jay krishnadas Ayurveda Series 102, 2012, Nidanasthana-Pramehanidanam-pages-503-510 \& Chikitsasthanam-pages 124-129. 
4. Prof. K.R. Srikantha Murthy, Ashtanga Sangraha of Vagbhata reprint edition, published by Chaukambha Orientalia, 2012. pages- 433.

5. Agnivesha, Charaka Samhita, Ayurveda- Dipika commentary by Chakrapanidutta, revised ed., Nidana Sthana (4:51), pg 215, Chaukhambha Surbharati Prakashan, Varanasi, (2005)

6. Agnivesha, Charaka Samhita, Ayurveda- Dipika commentary by Chakrapanidutta, revised ed., Chikitsa Sthana (3:115), pg. 407, Chaukhambha Surbharati Prakashan, Varanasi, (2005)

7. Dr Bulusu Sitaram, Bhavaprakasam of Bhavamisra first edition Varanasi, published by Chawkambha orientalia, chapter-38th, 2010, page-427.

8. Dr Bulusu Sitaram, Bhavaprakasam of Bhavamisra first edition Varanasi, published by Chawkambha orientalia, chapter-6th, 2010, page-135

9. Dr Bulusu Sitaram, Bhavaprakasam of Bhavamisra first edition Varanasi, published by Chawkambha orientalia, chapter-6th, 2010, page-138.

10. Dr Bulusu Sitaram, Bhavaprakasam of Bhavamisra first edition Varanasi, published by Chawkambha orientalia, chapter-6th, 2010, page-237-238.

11. Dr Bulusu Sitaram, Bhavaprakasam of Bhavamisra first edition Varanasi, published by Chawkambha orientalia, chapter-6th, 2010, page-444.

12. Dr KanjivLochan, Bhaisajyaratnavali of Shri Govinda Dasji, edition reprint,2014, Chaukhambha sanskrit Sansthan, chapter 37.

13. Dr Indradev Tripathi, Yogaratnakara with Vaidyaprabha Hindi commentary, $3^{\text {rd }}$ edition, Varanasi, Chowkhamba Krishnadas Academy, peg. 528

14. Bapalal G. Vaidya, Nighantu Adarsa, vol. I, edition 2008, Varanasi, published by Chaukhmbha Bharati Academy.

15. Wirstrom $\mathrm{T}$, Hilding $\mathrm{A}, \mathrm{Gu} \mathrm{Hf}$, Ostenson $\mathrm{CG}$, bjorklund a. Consumption of whole grain reduces the risk of deteriorating glucose tolerance, including progression to prediabetes. Am J Clin Nutr. 2013;97: 179187.

16. Krishnan s, Rosenberg 1, singer m, hu FB, djousse 1, Cupples la, palmer jr. Glycemic index, glycemic load, and cereal fibre intake and risk of type 2 diabetes in US black women. Arch Intern Med. 2007;167: 2304-2309.

17. Dorant E, van den B, Dorant PA, Goldbohm RA. Allium vegetable consumption, garlic supplement intake, and female breast carcinoma incidence. Breast Cancer Res Treatment. 1995; 33:163-70.
18. Madan Pal Nighantu: Bhasha Tatwa Praksahini Commentary by Vaidya Ram Prasad, Khem, Raj Sri Krishnadas, Bombay. Ma.P.Ni. Vatadi Varga.1998. P. 65

19. Madan Pal Nighantu: Bhasha Tatwa Praksahini Commentary by Vaidya Ram Prasad, Khem, Raj Sri Krishnadas, Bombay. Ma.P.Ni. Drakshadi Varga.1998. P. 72.

20. Liljeberg Elmståhl H., Björck I. Milk as a supplement to mixed meals may elevate postprandial insulinaemia. European Journal of Clinical Nutrition .2001;55(11):994-999.

21. Madan Pal Nighantu: Bhasha Tatwa Praksahini Commentary by Vaidya Ram Prasad, Khem, Raj Sri Krishnadas, Bombay. Ma.P.Ni. MareechadiVarga.1998. P. 37.

22. Prof. K.R. Srikantha Murthy, Susrutha Samhitha. Vol. I, Jay Krishna das Ayurveda Series 102, 2012, Sutrasthana - Annapanavidiadhyaya, pages-220.

23. Dr Bulusu Sitaram, Bhavaprakasam of Bhavamisra first edition Varanasi, published by Chawkambha orientalia, chapter-6th, 2010, page-130.

24. Adriana, N.M, Nutrition and health benefits of pulses. Punmedgov. 2014.

25. Bapalal, G, Adarsa Nighandu; Reprint Varanasi, published by Chawkamba visvabharati, Kusmandadi Varga, 2007, p. 638.

\section{Source of Support: Nil Conflict of Interest: None Declared}

How to cite this URL: Ripsa Raj K. P \& P Sudhakar Reddy: Pathyapathya In Prameha. International Ayurvedic Medical Journal \{online\} 2021 \{cited August 2021\} Available from: http://www.iamj.in/posts/images/upload/1806_1814.pdf 